Original Research Paper

\title{
PERAN ORANGTUA TERHADAP PENDAMPINGAN BELAJAR ANAK DARI RUMAH PADA MASA PANDEMI COVID-19
}

\author{
Susi Retnowati*, Herlina Siwi Widiana
}

\author{
Magister Psikologi Sains, Fakultas Psikologi, Universitas Ahmad Dahlan, Kampus \\ Jl. Pramuka No.42, Pandeyan, Kec. Umbulharjo, Yogyakarta
}

Email Corresponding:

susiretnowati160780@gmail.com

Page : 94-99

\section{Kata Kunci :}

Pandemi,

Pendampingan anak,

Peran orang tua

Keywords:

Pandemic,

Accompanying children,

The role of parents

\section{ABSTRAK}

Pandemi covid 19 menyebabkan pemerintah mengeluarkan aturan belajar dari rumah (learn from home) bagi anak-anak sekolah dan bekerja dari rumah (work from home) bagi guru dan pegawai. Situasi yang terjadi sekarang ini menuntut keterlibatan orang tua secara lebih maksimal. Artikel ini akan membahas peran orang tua dalam mendampingi anak di rumah selama pandemic. Metode yang digunakan yaitu metode studi pustaka dengan pengumpulan data menggunakan dokumentasi dari kajian teoritis yang didapatkan dari buku dan jurnal. Sejak terjadinya pandemik covid 19 pembelajaran yang dilakukan di rumah menjadikan peran orang tua menjadi sangat penting. Orang tua tidak hanya dituntut berfungsi sebagai tempat pendidikan anak yang pertama dan utama dalam membentuk karakter, nilai agama dan budi pekerti tetapi sekarang memiliki peran tambahan yaitu sebagai guru kedua bagi anak dalam belajar di rumah. Adapun peran penting orang tua dalam mendampingi anak yaitu orang tua sebagai pemberi semangat dan motivasi, memfasilitasi kebutuhan anak, tempat berdiskusi dan bertanya, membantu mengenali diri sendiri, melihat dan mengembangkan bakat anak dan menciptakan lingkungan yang kondusif untuk belajar

\section{ABSTRACT}

The Covid 19 pandemic has caused the government to issue a learn from home rule for school children and work from home for teachers and employees. The current situation demands maximum parental involvement. This article will discuss the role of parents in accompanying children at home during a pandemic. The method used is the literature study method with data collection using documentation from theoretical studies obtained from books and journals. Since the Covid 19 pandemic, learning carried out at home has made the role of parents very important. Parents are not only required to function as the first and foremost place for children's education in shaping character, religious values and character but now have an additional role, namely as a second teacher for children in learning at home. The important role of parents in accompanying children, namely parents as encouragement and motivation, facilitating children's needs, a place to discuss and ask questions, help identify themselves, see and develop children's talents and create an environment conducive to learning

\section{PENDAHULUAN}

Pada awal tahun 2020, dunia dihebohkan dengan adanya sebuah wabah berskala internasional yang disebabkan oleh sebuah virus, yaitu virus corona. Virus ini oleh World Health Organization (WHO) disebut sebagai Severe Acute Respiratory Syndrome Coronavirus-2 atau SARS-CoV-2 dan nama penyakitnya disebut sebagai Coronavirus
Disease 2019 atau Covid 19. Virus ini pertama kali muncul di kota Wuhan, China dengan tranmisinya penyebarannya adalah dari manusia ke manusia ${ }^{1}$. Dalam waktu singkat, virus tersebut sudah menyebar ke berbagai penjuru dunia, termasuknya di Indonesia. Penyebaran Covid 19 ini memberikan dampak luar biasa di berbagai bidang kehidupan seperti ekonomi, sosial, keagamaan, 
pendidikan, kesehatan, dan lainnya. Kementerian Pendidikan dan Kebudayaan memberikan instruksi agar para siswa-siswi belajar di rumah, tidak berangkat ke sekolah, melalui Surat Edaran Nomor 4 Tahun 2020 tentang Pelaksanaan Kebijakan Pendidikan dalam Masa Darurat Penyebaran Covid 19. Dan menetapkan aturan belajar dari rumah (learn from home) bagi anak-anak sekolah dan bekerja dari rumah (work from home) bagi guru, termasuk mereka yang bekerja di satuan PAUD. Untuk pendidikan di Indonesia, kondisi ini merupakan hal yang tak terduga bagi guru, orang tua, dan anak. Guru, orang tua, dan anak-anak secara tiba-tiba harus mencari cara agar proses belajar tetap berjalan agar perkembangan anak tetap optimal meskipun mereka tetap rumah.

Agar siswa dapat belajar di rumah, demi keamanan dan kesehatan kita semua, hal ini tentunya berdampak untuk orang tua, dimana orang tua harus memberikan pembelajaran pada anaknya di rumah. Tentu terjadi berbagai pendapat mengenai hal ini, banyak orang tua yang mengungkapkan bahwa mereka merasa keberatan ketika anak belajar di rumah, karena di rumah anak merasa bukan waktunya belajar namun mereka cenderung menyukai bermain saat di rumah, walaupun di situasi pamdemi seperti ini. Maka dsni akan terlihat bagaimana pola asuh orang tua saat belajar di rumah. Berkaitan dengan hal tersebut, sesuai dengan penelitian dari Khasanah (2020) pada awalnya banyak orang tua yang menolak pembelajaran daring untuk anaknya, karena mereka masing- masing dengan teknologi ${ }^{2}$. Namun seiringnya waktu, orang tua mulai menerima pembelaran daring $\mathrm{ini}^{3}$. Mengingat pentingnya peranan orang tua dalam mendidik anak, beberapa penelitian telah membuktikan bahwa orang tua memiliki andil yang sangat besar dalam kemampuan anak dalam lingkup Pendidikan. Salah satunya penelitian yang dilakukan Valeza (2017) dimana penelitian ini menunjukkan peran orang tua dalam menentukan prestasi belajar siswa sangatlah besar. Pendidikan anaknya dapat menyebabkan anak kurang atau bahkan tidak berhasil dalam belajarnya. Sebaliknya, orang tua yang selalu memberi perhatian pada anaknya, terutama perhatian pada kegiatan belajar mereka dirumah, akan membuat anak lebih giat dan lebih bersemangat dalam belajar karena ia tahu bahwa bukan dirinya sendiri saja yang berkeinginan untuk maju, akan tetapi orang tuanya juga memiliki keinginan yang sama. Sehingga hasil belajar atau prestasi belajar yang diraih oleh siswa menjadi lebih baik $^{4}$.

Peran orang tua dalam pendidikan merupakan sesuatu yang sangat penting untuk menentukan keberhasilan pendidikan anakanaknya. Pendidik pertama dan utama adalah orang tua. Nur (2015) menyatakan bahwa "peran orang tua dalam pendidikan adalah sebagai pendidik, pendorong, fasilitator dan pembimbing"5.

Orang tua mempunyai andil yang sangat besar dalam memotivasi anak. Anak yang memiliki motivasi maka akan semangat dan rajin dalam belajar sehingga memperoleh hasil belajar yang memuaskan. Menurut Rizkiyah (2015) "peran orang tua dalam memotivasi belajar anak yaitu menanamkan cinta belajar, membagi waktu belajar anak, dan memberikan motivasi dalam mengerjakan tugas sekolah"6. Rumbewas menyatakan bahwa "peran orang tua dalam memotivasi belajar siswa yaitu mengontrol waktu belajar, memantau perkembangan kemampuan akademik anak, memantau perkembangan kepribadian anak mencakup sikap moral dan tingkah laku anak, dan memantau efektifitas jam belajar disekolah"7. Rumbewas (2018) menyatakan bahwa "cara untuk meningkatkan motivasi belajar siswa yaitu menciptakan iklim rumah yang mendukung anak untuk belajar, menyediakan waktu yang cukup untuk terlibat dalam kegiatan belajar anak dan memberikan 
penghargaan atau respon positif terhadap setiap usaha anak"7.

\section{METODE}

Artikel ini menggunakan metode studi pustaka. Metode studi pustaka adalah serangkaian kegiatan yang berkenaan dengan metode pengumpulan data pustaka, membaca dan mencatat serta mengolah bahan bahan penelitian $^{8}$. Penelitian yang menggunakan bahan-bahan bacaan sebagai sumber rujukan ${ }^{9}$. Teknik pengumpulan data menggunakan dokumentasi. Dokumentasi diperoleh melalui kajian teoritis yang didapatkan dari buku dan jurnal. Artikel ini membahas peran orang tua dalam mendampingi anak di rumah.

\section{HASIL DAN PEMBAHASAN}

Berdasarkan hasil analisis dari beberapa jurnal publikasi yang penulis kaji, maka diperoleh hasil kajian sebagai berikut:

Tujuan penelitian ini adalah untuk melihat bagaimana pola asuh orang tua selama pembelajaran di rumah atau study from home melalui daring dalam membimbing anakanaknya sebagai upaya memutus penyebaran covid 19. Berdasarkan hasil penelitian dapat diketahui bahwa orang tua merasa pembelajaran di rumah sangat efektif di terapkan, namun bukan berarti pembelajaran di sekolah tidak efektif. Hal ini karena pembelajaran di rumah cenderung pemberian tugas yang dalam pengerjaannya bisa di bantu oleh orang tua di rumah, dalam pembelajaran untuk memahami konsep, kemudian mengembangkan konsep itu sampai refleksi, tidak berjalan dengan sebaik itu ${ }^{10}$.

Pendidikan pada anak usia dini pada dasarnya meliputi seluruh upaya dan tindakan yang dilakukan oleh pendidik dan orang tua dalam perawatan, pengasuhan, dan pendidikan pada anak dengan menciptakan aura dan lingkungan dimana anak dapat mengeksplorasi pengalaman yang memberikan kesempatan kepadanya untuk mengetahui dan memahami pengalaman belajar yang diperolehnya dari lingkungan, melalui cara mengamati, meniru, dan bereksperimen yang berlangsung secara berulang-ulang dan melibatkan seluruh potensi dan kecerdasan anak ${ }^{11}$.

$$
\text { Pendidikan pada anak harus }
$$
memberikan kesempatan bagi anak untuk mengenal lingkungannya. Pendidikan yang diberikan pada anak diperlukan untuk dapat mengembangkan potensi yang dimiliki anak agar menjadi optimal. Keterbatasan yang dimiliki orang tua tentang pendidikan anak membuat para orang tua meminta bantuan lembaga PAUD, akibatnya pendidikan anak lebih banyak dilakukan di lembaga PAUD. Hal tersebut didukung oleh pendapat dari Umar yang menyatakan bahwa pendidikan di luar keluarga, bukan dalam arti melepaskan tanggung jawab orang tua dalam pendidikan anak, tetapi hal itu dilakukan orangtua semata-mata karena keterbatasan ilmu yang dimiliki oleh orang tua, karena sifat ilmu yang terus berkembang mengikuti perkembangan zaman, sementara orang tua memiliki keterbatasan-keterbatasan $^{12}$. Orang tua mempercayakan pendidikan anak mereka kepada lembaga PAUD agar perkembangan anak mereka tetap optimal.

Sejak terjadinya pandemik covid 19 pendidikan anak dilakukan dengan jarak jauh. Pembelajaran jarak jauh dilakukan dengan memanfaatkan teknologi yang ada sehingga anak dan orang tua tetap bisa berintekasi dengan guru. Namun dalam implementasinya, pelaksanaan pendidikan jarak jauh tidak selalu berjalan mulus, khusus dalam pendidikan anak usia dini. Kenyataannya, masih banyak keluhan dari guru mengenai kesulitan dalam mengoperasikan komputer, mengakses jaringan internet, internet tidak stabil, kesulitan mengkomunikasikan pesan ke orangtua, kesulitan menyusun perencanaan pembelajaran yang sederhana dan sesuai untuk diterapkan anak di rumah melalui orangtua, dan juga kesulitan guru dalam melakukan 
penilaian terhadap hasil belajar anak di rumah. Di sisi lain, keluhan juga datang dari orangtua, yaitu kesulitan mendampingi anak belajar karena belum paham caranya, tidak biasa menggunakan teknologi digital untuk pembelajaran anak, dan tidak memahami maksud pesan yang disampaikan guru.

Kebijakan mengenai belajar di rumah tersebut tidak hanya menuntut inovasi pembelajaran yang dilakukan oleh guru tetapi juga menuntut dimaksimalkannya kembali peran orang tua dalam mengasuh, mendampingi, dan memfasilitasi anak dalam belajar, pengasuhan, pendampingan dan peran orang tua sebagai pendidik sekarang ini memiliki pengaruh yang besar terhadap perkembangan anak usia dini ${ }^{13}$. Pembelajaran yang dilakukan di rumah menjadikan peran orang tua menjadi sangat penting. Orang tua harus dapat memfasilitasi kegiatan belajar yang dilakukan oleh anak. Hal tersebut sesuai dengan pendapat dari Iriani yang menyatakan bahwa pendidikan harus dilakukan sedini mungkin di rumah, peran dan tanggung jawab itu ada di pundak orang tua karena orang tua adalah pendidik utama dalam keluarga, bukan semata masalah intelektual tetapi pendidikan untuk pembentukan kepribadian yang luhur. Peran tersebut sering disebut dengan pendidikan anak dalam keluarga ${ }^{14}$.

Keluarga merupakan wadah pendidikan yang sangat besar pengaruhnya dalam perkembangan motivasi belajar anak oleh karena itu pendidikan anak tidak dapat dipisahkan dari keluarganya, karena keluarga merupakan tempat pertama kali anak belajar menyatakan diri sebagai makhluk sosial dalam berinteraksi dengan kelompoknya ${ }^{15}$. Keluarga, utamanya orang tua adalah peletak dasar pertama bagi perkembangan anak. Orang tua selama pandemik Covid-19 tidak hanya berfungsi sebagai tempat pendidikan anak yang pertama dan utama dalam membentuk karakter, nilai agama dan budi pekerti tetapi sekarang memiliki peran tambahan sebagai guru kedua bagi anak dalam belajar di rumah. Peran penting orang tua selama proses pembelajaran dari rumah adalah menjaga motivasi anak, memfasilitasi anak belajar, menumbuhkan kreativitas anak, mengawasi anak, dan mengevaluasi hasil belajar ${ }^{16}$.

Mendampingi anak ketika belajar adalah sesuatu yang sangat penting bagi anak yaitu dapat membangun kedekatan antara orang tua dengan anak, belajar mengajaknya berdiskusi agar mengetahui bagaimana pola berpikir anak. Adapun Peran penting orang tua dalam mendampingi anak yaitu ${ }^{17}$ (Sundari 2018): (i) Orang tua sebagai pemberi semangat. Orang tua memberikan semangat kepada anak. Semangat tersebut dapat berupa kata-kata yang menimbulkan dorongan dalam diri anak. sebagai media untuk pemacu semangat, perlu pasangkan slogan atau kata mutiara dalam pembelajaran anak usia dini dapat menciptakan suasana yang positif pada anak $^{18}$. Dengan kata-kata tersebut anak lebih percaya diri untuk melakukan sesuatu. (ii) Memfasilitasi kebutuhan anak. Orang tua dapat memfasilitasi kebutuhan anak untuk kegiatan belajarnya di rumah agar perkembangan anak dapat tetap optimal. Pembelajaran dapat disesuaikan dengan apa yang telah dapat dari sekolah, agar tetap terjadi kesinambungan antara yang didapatkan anak di sekolah dan di rumah. Hal tersebut sesuai dengan pendapat Latif yang menyatakan bahwa orang tua dapat memfasilitasi kegiatan anak di rumah yang disesuaikan dengan pembelajaran anak di lembaga Pendidikan seperti menyediakan buku-buku sesuai dengan tema yang tengah dibahas di sekolah/lembaga, serta mainanmainan yang menunjang pembelajaran sesuai tema di sekolah/lembaga ${ }^{19}$. (iii) Tempat berdiskusi dan bertanya. Orang tua adalah tempat sosial pertama bagi anak. Peran orang tua di rumah juga dapat dijadikan teman diskusi. Anak akan lebih terbuka jika orang 
tuanya juga terbuka dan memberi waktu luang untuk berdiskusi ${ }^{20}$ anak memiliki rasa ingin tahu yang besar sehingga mereka akan bertanya apapun kepada orang tua. Hal ini sesuai dengan pendapat Pebria, seorang anak untuk memaksimalkan potensi yang dimilikinya, membutuhkan seseorang untuk berdiskusi supaya memberikan jawaban kepada anak dan memotivasi anak ${ }^{21}$. Oleh karena itu, sangat penting untuk orang tua dapat memberikan waktu bersama anak untuk berdiskusi dan menjawab pertanyaanpertanyaan dari anak. (iv) Membantu mengenali diri sendiri Mengenali diri sendiri sebagai sarana memudahkan kita untuk memahami orang lain ${ }^{22}$. Anak membangun jati dirinya bersama orang terdekat. Disinilah peran orang tua untuk membentuk karakter dan sikap anak agar terbentuk pribadi yang baik. (v) Melihat dan mengembangkan bakat anak Orang tua harus dan mampu bertanggung jawab untuk menemukan bakat dan minat anak, sehingga anak diasuh dan dididik, baik langsung oleh orangtua atau melalui bantuan orang lain, seperti guru, sesuai dengan bakat dan minat anak sendiri, sehingga anak dapat memperoleh prestasi belajar secara lebih optimal $^{12}$. (vi) Menciptakan lingkungan yang kondusif untuk belajar. Orang tua harus dapat menciptakan lingkungan dan suasana belajar yang nyaman sehingga anak dapat belajar dengan baik. Suasana belajar dibuat secara (alami), hangat, menarik, dan menyenangkan, dengan demikian suasana belajar akan berjalan secara alami dan tidak mengikat anak ${ }^{23}$.

\section{KESIMPULAN}

Pandemi covid 19 memberikan dampak yang besar, termasuk pada pendidikan di lembaga PAUD. Adanya kebijakan dari Pemerintah dengan menerapkan belajar dari rumah sebagai bentuk penanggulangan penyebaran virus corona menyebabkan pola pembelajaran berubah dari belajar di sekolah menjadi belajar dari rumah. Kegiatan belajar dari rumah dapat menjadi titik balik digalakkannya kembali peran keluarga. Keluarga, utamanya orang tua memegang peranan yang sangat penting dalam perkembangan karena orang tualah yang paling banyak berinteraksi dengan anak sehingga orang tua dapat memaksimalkan peran utamanya dalam mendidik anak mereka.

\section{SARAN}

Orang tua sebagai pendidik utama anak selama belajar dari rumah harus menyediakan waktu, lingkungan belajar yang menyenangkan dan sumber belajar yangberagam agar anak tetap dapat mengembangkan kemampuannya dan mencapai tugas - tugas perkembangannya.

Dengan mendampingi anak di rumah dapat membangun kedekatan hubungan antara orang tua dan anak. Adapun peran penting orang tua dalam mendampingi anak yaitu Anak merasa tidak sendiri, orang tua sebagai pemberi semangat, memfasilitasi kebutuhan anak, tempat berdiskusi dan bertanya, membantu mengenali diri sendiri, melihat dan mengembangkan bakat anak dan menciptakan lingkungan yang kondusif untuk belajar.

\section{UCAPAN TERIMAKASIH}

Terimakasih atas semua pihak yang telah membantu dalam penyelesaian penelitian ini.

\section{DAFTAR PUSTAKA}

1. Relman Da. Opinion: To Stop The Next Pandemic, We Need To Unravel The Origins Of Covid-19. Proc Natl Acad Sci. 2020;117(47):29246-29248.

Doi:10.1073/Pnas.2021133117

2. Khasanah M. Page 1 Dampak Pembelajaran Daring Terhadap Prestasibelajar Ips Pada Siswa Kelas Iv Di Sd Tahfidz Ar-Risalahkec. Bandungan Tahun Pelajaran 2019/2020. Published Online 2020.

3. Shereen Ma, Khan S, Kazmi A, Bashir N, Siddique R. Covid-19 Infection: Emergence, Transmission, And 
Characteristics Of Human Coronaviruses. J Adv Res. 2020;24:91-98. Doi:10.1016/J.Jare.2020.03.005

4. Valeza Ar. Peran Orang Tua Dalam Meningkatkan Prestasi Anak Di Perum Tanjung Raya Permai Kelurahan Pematang Wangi Kecamatan Tanjung Senang Bandar Lampung. Published Online November 20, 2017.

5. Aisyatinnaba N. Peran Orang Tua Dalam Memotivasibelajar Siswa( Studi Kasus Pada Siswa Kelas Viii Smp Negeri 03kecamatan Losari, Kabupaten Brebes). Published Online 2015.

6. Rizkiyah H. Peran Orangtua Dalam Meningkatkan Minat Belajar Anak Sekolah Dasar (6-12 Tahun) Di Dusun Kalikajang Kelurahan Gebang Sidoarjo. J+Plus Unesa. 2015;4(1). Https://Jurnalmahasiswa.Unesa.Ac.Id/Ind ex.Php/Jurnal-Pendidikan-Luar-

Sekolah/Article/View/13227

7. Rumbewas Ss, Laka Bm, Meokbun N. Peran Orang Tua Dalam Miningkatkan Motivasi Belajar Peserta Didik Di Sd Negeri Saribi. Edumatsains $J$ Pendidikan, Mat Dan Sains. 2018;2(2):201-212.

Doi:10.33541/Edumatsains.V2i2.607

8. Zed M. Metode Penelitian Kepustakaan. Yayasan Obor Indonesia; 2008.

9. Nata A. Metodologi Studi Islam. Rajawali Press; 2004.

10. Simha A, Prasad Rv, Narayana S. A Simple Stochastic Sir Model For Covid 19 Infection Dynamics For Karnataka: Learning From Europe. Published Online March 26, 2020.

11. Sujiono Yn. Konsep Dasar Pendidikan Anak Usia Dini. Pt Indeks; 2009.

12. Umar M, Umar M. Peranan Orang Tua Dalam Peningkatan Prestasi Belajar Anak. J Edukasi J Bimbing Konseling. 2015;1(1):20-28.

Doi:10.22373/Je.V1i1.315

13. Lestari N, G A, M Y. Pendidikan Anak Usia Dini Di Masa Pandemi Covid19. Yayasan Kita Menulis; 2020.

14. Iriani D. Kesalahan Dalam Mendidik Anak. Gramedia

15. Anwar S. Hubungan Pola Asuh Orang Tua Dengan Motivasi Belajar Anak. $J$
Syst Indragiri. 2017;1(2):58-65.

16. Trisnadewi K, Muliani Nm. Pembelajaran Daring Di Masa Pandemi Covid-19. Vol 1. Yayasan Kita Menulis; 2020.

17. Sundari S, Sinuraya Y Ambiya. Langkah Kakiku Setelah Sma. Publica Institue Jakarta; 2018.

18. Fadillah M. Edutainment Pendidikan Anak Usia Dini, Menciptakan Pembelajaran Menarik, Kreatif, Dan Menyenangkan. Kencana; 2014.

19. Latif M, Zukharina, Dkk. Orientasi Baru Pendidikan Anak Usiadini. Kencana Prenada Media Group; 2013.

20. Fakhriza Z. Quo Vadis Pendidikan Indonesia? Guepedia; 2018.

21. Wenda Ap. How Maximizingchild Potential. Pt Elex Media Komputindo; 2019.

22. Prashnig B. The Power Of Learning Styles. Kaifa

23. Erzad Am. Peran Orang Tua Dalam Mendidik Anak Sejak Dini Di Lingkungan Keluarga. Thufula $J$ Inov Pendidik Guru Raudhatul Athfal. 2018;5(2):414-431.

Doi:10.21043/Thufula.V5i2.3483 